\title{
ЛАЗЕРНИЙ СПЕКЛ-КОНТРАСТНИЙ АНАЛІЗ ДЛЯ ДОСЛІДЖЕННЯ МІКРОЦИРКУЛЯЦІї В СУДИНАХ
}

\author{
Богомолов М.Ф.,к.т.н., доцент \\ nbogom@yahoo.com \\ Пузик М.Ю., бакалавр \\ Max.Puzyk@gmail.com \\ Кафедра біомедичної інженерії \\ Національного технічного університету України \\ «Київський політехнічний інститут імені Ігоря Сікорського», \\ м. Київ, Україна
}

\begin{abstract}
Реферат - Запропонована розробка діагностичного лазерного пристрою, що використовує методику спекл-контрастного аналізу іп vivo для дослідження мікроциркуляиії в судинах. Проведений короткий огляд існуючих методів дослідження мікрочиркулящії. Розглянуті основні особливості методики вимірювання лазерного спекл-контрастного аналізу Запропоновано загальну структурну схему діагностичного пристрою з вказаними моделями компонентів. Ключові слова-Мікроциркуляція, спекл, спекл-контрастний аналіз.
\end{abstract}

\section{І.ВСТУП}

Система мікроциркуляції $\epsilon$ найменшою функціональною одиницею судинної системи, де мікросудини оточують тканинні клітини, які вони постачають нутрієнтами i від яких видаляють продукти метаболізму. Дана область системи кровопостачання включає артеріоли, кровоносні капіляри, венули, а також лімфатичні капіляри i інтерстиціальний простір. Система мікроциркуляції - одна 3 тих важливих систем, в яких різні хвороби проявляються на ранніх стадіях. При цьому порушення мікроциркуляції можуть бути не тільки вторинними, а й першопричиною багатьох захворювань, визначаючи в подальшому їх результат.

Дослідження судин та мікроциркуляції під впливом різних факторів залишається актуальною проблемою i дозволяє виявляти закономірності в аспекті дисфункції цієї важливої ланки організму. Інформація про мікроциркуляцію може знадобитися, якщо у людини $\epsilon$ патологія, яка зачіпає кровоносні судини мозку, серця, легень, нирок, кінцівок або інших частин тіла.
Велика кількість захворювань нерозривно пов'язана 3 тими чи іншими порушеннями окремих ланок мікроциркуляції, а саме атеросклероз, артеріальна гіпертензія, ендотоксемії i сепсис, діабетична нефропатія, венозна недостатність та багато інших. Моніторування мікроциркуляторної функції в клініці досить обмежене як через малу кількість існуючих безпечних методів дослідження, так і внаслідок складності інтерпретації одержуваних даних. Медичні працівники можуть використовувати данні цих досліджень, щоб дізнатися більше про стан хворого i вибрати найкращий спосіб лікування. Тому важливо обрати кращий метод дослідження судин для конкретної проблеми.

Для виміру циркуляції крові існує багато методів. Одним з найпоширеніших $є$ методика пульсової оксиметрії, заснована на використанні принципів фотоплетизмографії (ФПГ), що дозволяють виділити артеріальну складову абсорбції світла для визначення оксигенації артеріальної крові.

Пульсограма відображає, перш за все, ритмічні коливання капілярного 
кровотоку, викликані перемішенням артеріальної крові під впливом м'язових скорочень лівого шлуночка серця. Контур периферичної об'ємної пульсової хвилі, отриманий за допомогою фотоплетизмографії, визначається головним чином характеристиками великого кола кровообігу, швидкістю поширення хвилі тиску в аорті і великих еластичних артеріях, тому для вимірювання мікроциркуляції його використання не ефективним [1].

Методи інфрачервоної термографії та візуалізації. Оскільки температура всередині організму вище температури поверхневих тканин (шкіри), а кров $\epsilon$ однією з основних ланок терморегуляції, то очевидно, зі зміною мікроциркуляції, наприклад, в шкірі, повинна змінюватися i температура іiі поверхні. Але у методу існує ряд недоліків. По-перше потужність електромагнітного випромінювання тіла може змінюватися в залежності від двох факторів: за рахунок температури або за рахунок інтегральної випромінювальної здатності (ступеня чорноти) тіла. Одиниця в другому знаку після коми в значенні ступеня чорноти тіла дає внесок в визначення температури близько $1^{\circ} \mathrm{C}$, a вимірювати це значення вкрай важко. Подруге сама зміна температури в медицині має багато різних причин. Далеко не завжди знання температури, особливо локальної, може допомогти в проясненні патогенезу та етіології захворювання, це занадто непряма технологія оцінки процесів мікроциркуляції крові [2].

Лазерна допплерівська флоуметрія (ЛДФ) - безконтактна методика зондування капілярів світлом лазера 3 метою діагностики стану мікроциркуляції крові в органах і тканинах. Метод грунтується на визначенні перфузії тканини кров'ю шляхом вимірювання допплерівського зсуву частот, що виникає при зондуванні тканини лазерним випромінюванням, 3 подальшою реєстрацією випромінювання, відбитого від рухомих i нерухомих компонентів тканини. Одержуваний при ЛДФ сигнал характеризує кровотік в мікросудинах в обсязі до 1,5 мм ${ }^{3}$ тканини [3].
Прилади - лазерні допплерівські флоуметри, які реалізують цю технологію, в більшості своїй містять напівпровідниковий лазер (лазерний діод) для формування вузькосмугового когерентного зондуючого випромінювання i оптичні волокна для доставки випромінювання до зони обстеження i назад. Схема приладу виявляється складною і дорогою за рахунок лазера i оптичних волокон, а також чутливою до найменших коливань волокна. Від вібрації волокна виникають артефакти в записі, які обмежують використання приладу для діагностики пацієнта в русі [2].

Багатообіцяючим

напрямком вважається лазерна діагностика 3 використанням аналізу розсіяного від біооб'єктів світла. Наразі напрям достатньо новий і потребує подальшого дослідження. Спекл-інтерферометрична картина утворюється 3 розсіяного світла при використанні когерентного лазерного випромінювання. Основу методу складає статистичний аналіз інтерференційних спекл-картин, що утворюються на поверхні випадково-неоднорідного напівпрозорого середовища в результаті розсіювання лазерного випромінювання. Лазерна спеклконтрастна візуалізація успішно використовується для аналізу кровотоку i лімфотоку в пухлинних тканинах, оцінки впливу алергенів i оптичних просвітлюючих агентів на мікроциркуляцію крові в шкірі, моніторингу мозкового кровотоку, моніторингу перфузії шкіри тощо. Перевагами лазерної спекл-контрастної візуалізації $є$ можливість спостереження за кровотоком і перфузією біологічних тканин в реальному часі, можливість проведення як інвазивних, так i неінвазивних вимірювань, а також відносна дешевизна експериментальної установки[4].

\section{II. ПОСТАНОВКА ЗАДАЧІ}

У даній статті наводиться методика виміру лазерного спекл-контрастного аналізу а також схема лазерного спеклконтрастного аналізатора для дослідження мікроциркуляції крові в судинах з вибором конкретних компонентів. 


\section{III. МЕТОДИКА ВИМІРЮВАНЬ}

Фактично лазерні спекли $\epsilon$ випадковою інтерференційною картиною, що виникає внаслідок взаємодії когерентного світла 3 розсіюючою поверхнею і (або) з мутним негомогенним середовищем. $\mathrm{B}$ експериментального спостереже зображення, що формується на кожному пікселі фотодетектора (ПЗС або КМОП камера), $є$ суперпозицією безлічі амплітудних функцій розсіювання, кожна 3 яких виникає від різних точок розсіювання середовища, що спостерігається. Таким чином, функції розсіювання мають різні фази, що і призводить до виникнення випадкової інтерференційної картини, яка отримала назву спекла або спекл-структури [4].

Як було зазначено, спекл-картина може спостерігатися при інтерференції хвиль від окремих неоднорідностей поверхні шорсткого об'єкта та при детектуванні світла, яке пройшло через напівпрозорий об'єкт. Для пристрою, розглянутого в цій роботі, більш цікавий перший метод (рис. 1).

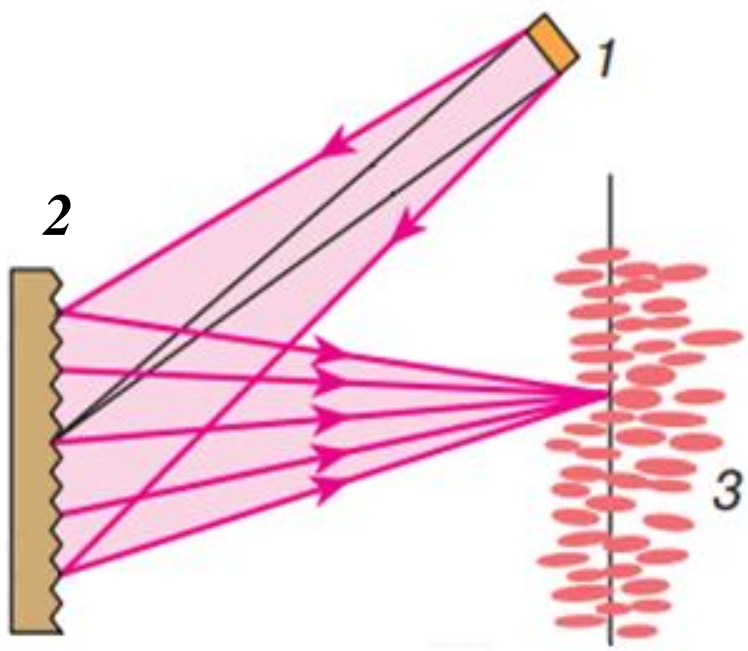

Рисунок 1 - Оптична схема спостереження спекл-картини при взаємодії 3 шорсткою поверхнею: 1 - джерело світла; 2 - випадковонеоднорідний об'єкт; 3 - схематичний вигляд поздовжнього перерізу шару спекл-структури.

\begin{tabular}{lrr}
\multicolumn{2}{c}{ Виявилося, що } & зображення \\
відображеного & об'єкта, & освітленого \\
когерентним & \multicolumn{2}{c}{ випромінюванням, } \\
представляє & складну & гранулярну \\
структуру, яка & не має явного зв'язку 3
\end{tabular}

мікроскопічними властивостями об'єкту, що освітлюється. Більшість відбиваючих поверхонь екстремально шорсткі в порівнянні 3 довжиною хвилі джерела випромінювання. Можна вважати, що основний внесок в розсіювання вносять малі ділянки поверхні 3 центрами в дзеркально відбитих точках. Зі збільшенням крутизни шорсткостей i величини освітлюваної області число точок випромінювання зростає. Хвиля, відбита від такої поверхні складається 3 «вкладів» від великого числа малих ділянок поверхні, які можна вважати незалежними областями, що розсіюють. Поширення цього відбитого випромінювання до області спостереження призводить до того, що в заданій точці спостереження складаються розсіяні компоненти кожен зі своєю затримкою. Інтерференція цих дефазованих, але когерентних хвиль, призводить до гранулярної спекл-картини.

Зміни локальної динаміки в спостережуваному об'єкті (рух розсіюючих частинок) призводить до флуктуацій спеклструктури. Детектування подібної спеклструктури за допомогою камери з кінцевим часом експозиції призводить до розмиття одержуваного спекл-зображення в областях, що відповідають руху розсіюючих частинок. Більш того, чим інтенсивніше рух в спостережуваному об'єкті, тим більш розмитим буде спеклзображення, реєстроване камерою. Статистичний аналіз спекл-структури дозволяє оцінити середню швидкість частинок в середовищі [4].

Для такої оцінки був введений параметр - спекл-контраст К [5]:

$$
K=\frac{\sigma}{\langle I\rangle}
$$

де $\langle I\rangle$ - середня інтенсивність спеклструктури, $\sigma$ - стандартне відхилення інтенсивності. Теоретично $\langle I\rangle$ і $\sigma$ рівні в разі ідеально сформованої спеклструктури. 3 чого випливає, що в даному випадку значення спекл-контрасту має приймати значення 1. Проте властивості використовуваної оптичної системи, властивості самого об'єкта, що спостерігається, а також когерентні властивості лазерного джерела впливають 
на формування спекл-структури, внаслідок чого на практиці спекл-контраст приймає значення між 0 і 1 [4].

При цьому контраст може визначатися як по простору огляду (просторовий контраст), так i в часі (часовий контраст) в залежності від обраної моделі спостереження та усереднення поля. Також можливе визначення змішаного контрасту. Як було показано в [5], контраст може бути виражений через нормовану функцію автокореляції першого порядку за формулою:

$$
\begin{gathered}
\mathrm{K}(\mathrm{T})=\left[\frac{2 \beta}{T} \int_{0}^{T}\left|\frac{g_{1}(\tau)}{g_{1}(0)}\right|^{2}(1\right. \\
\left.\left.-\frac{\tau}{T}\right) d \tau\right]^{\frac{1}{2}}
\end{gathered}
$$

де Т - обраний часовий інтервал інтегрування (зазвичай 5-6 мс), $\beta$ - $€$ коефіцієнтом мультиплікативного зменшення спекл-контрасту, пов'язаного 3 такими факторами, як поляризація, ефекти когерентності i невідповідність між розміром пікселя камери $\mathrm{i}$ середнім розміром спекла [2].

Залежно від ступеня руху розсіювачів у видимій області, рівень розмиття спекл-зображення буде відрізнятися. Чим більше руху розсіювачів $\epsilon$ в зображенні, тим більше розмитим воно буде. Рівень розмиття можна виміряти за допомогою усередненого контрасту зображення спеклу. Якщо $\epsilon$ рух розсіювачів, стандартне відхилення інтенсивності буде зменшуватися, i, отже, контраст спекл-зображення буде нижче.

Одним 3 найважливіших параметрів при дослідженнях контрасту є тривалість реєстрації спекл зображення - час експозиції. Незважаючи на те, що існує можливість (в певних межах) програмно керувати експозицією камери, в реальному експерименті можуть бути встановлені обмеження, що не дозволяють вибирати іiі будь-яке доступне значення. Так, у зв'язку з різними коефіцієнтами поглинання i розсіяння у різних зразків, а також 3 відмінностями їх внутрішньої динаміки, при незмінній інтенсивності падаючого випромінювання спостерігаються істотні відмінності в статистиці реєстрованого розподілу флуктуацій інтенсивності, отже, і в розрахованому на його основі контрасті. Проте, в разі недостатнього часу накопичення або занадто великої кількості світла, що падає на світлочутливі елементи камери за час експозиції, статистика флуктуацій інтенсивності реєстрованого зображення спотворюється. Це відбувається через недостатню чутливість або «перенавантаження» світлочутливих елементів детектора. Для здійснення вимірювань в режимі реального часу необхідно проводити усереднення спекл зображень за час від 5 до 30 мс [6].

Для коректного виміру та аналізу спекл-зображень розробники створюють програми, що дозволяють вимірювати та налаштовувати найважливіші параметри. Так в роботі [6] авторка розробила програму, яка в режимі реального часу 3 частотою до 100 кадрів в секунду реєструє розподіл інтенсивності спекл-поля i розраховує за формулою (1) у зазначеній оператором області середній контраст або його просторовий розподіл 3 паралельною візуалізацією. Також, при вимірюванні контрасту програма враховує та коригує час експозиції КМОП-камери, що в роботі дорівнював 10 мс.

\section{CХЕМА ПРИЛАДУ ТА ВИБІР СКЛАДОВИХ}

Експериментальна установка для даної методики проста: лазерне світло, що розходиться, висвітлює об'єкт, який знаходиться під детектором (КМОПкамера або еквівалент). Дані передаються на персональний комп'ютер для обробки за допомогою спеціалізованого програмного забезпечення, у оператора також $\epsilon$ параметри, які можна регулювати. В оригінальній методиці лазерного спеклконтрастного аналізу ці параметри включали в себе час експозиції, кількість пікселів, час, протягом якого був обчислений локальний контраст, вибір кольорів для кодування контрастності. Вибір кількості пікселів, для обчислення контрасту спеклів дуже важливий момент: занадто мало пікселів і статистика буде порушена, занадто багато, і просторова 
роздільна здатність зменшиться. Зазвичай в дослідженнях використовують $5 \times 5$ або 7х7 матриці пікселів.

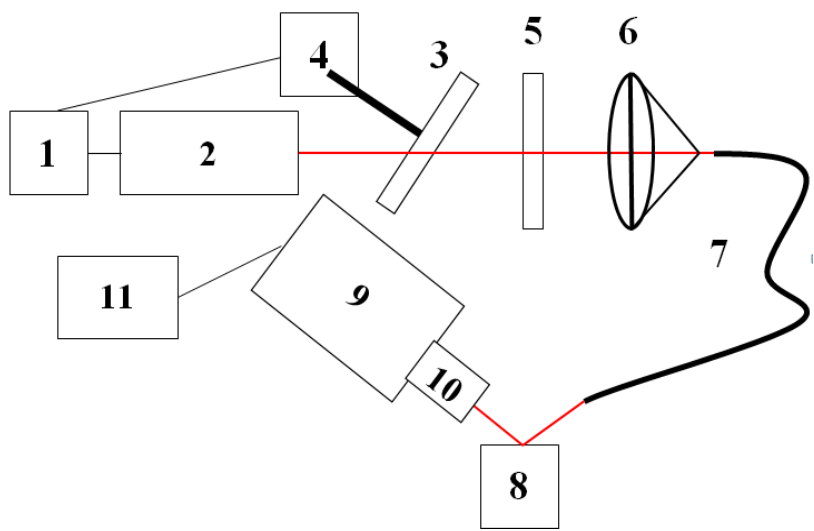

Рисунок 2 - Узагальнена структурна схема діагностичного пристрою: 1 - Блок комутації та живлення; 2 - Джерело лазерного випромінювання; 3 - Дифузор; 4 - Обертовий двигун дифузора; 5 - поляризатор; 6 Фокусуючий об'єктив; 7 - Гнучке оптоволокно; 8 — біологічний об'єкт; 9 - КМОП камера; 10 Об'єктив КМОП камери; 11 - ПК.

Однією 3 найважливіших деталей схеми є лазерне джерело випромінювання. В роботі [7] підняли питання про те який діодний лазер краще обрати, та як спектральна ширина джерела світла впливає на спекл-структуру і які наслідки несе для in vivo лазерної спекл-візуалізації. Були продемонстровані результати дослідження, в яких при всіх виміряних швидкостях кровотоку лазер зі стабілізованою довжиною хвилі давав найкращі значення часового контрасту (рис. 3). Загальний же контраст дорівнював 0,83 , що приблизно на $30 \%$ краще за аналоги без стабілізації. Тому було прийнято рішення взяти лазерний діод LP785-SAV50 3 довжиною хвилі 785 нм та потужністю 50 мВт.

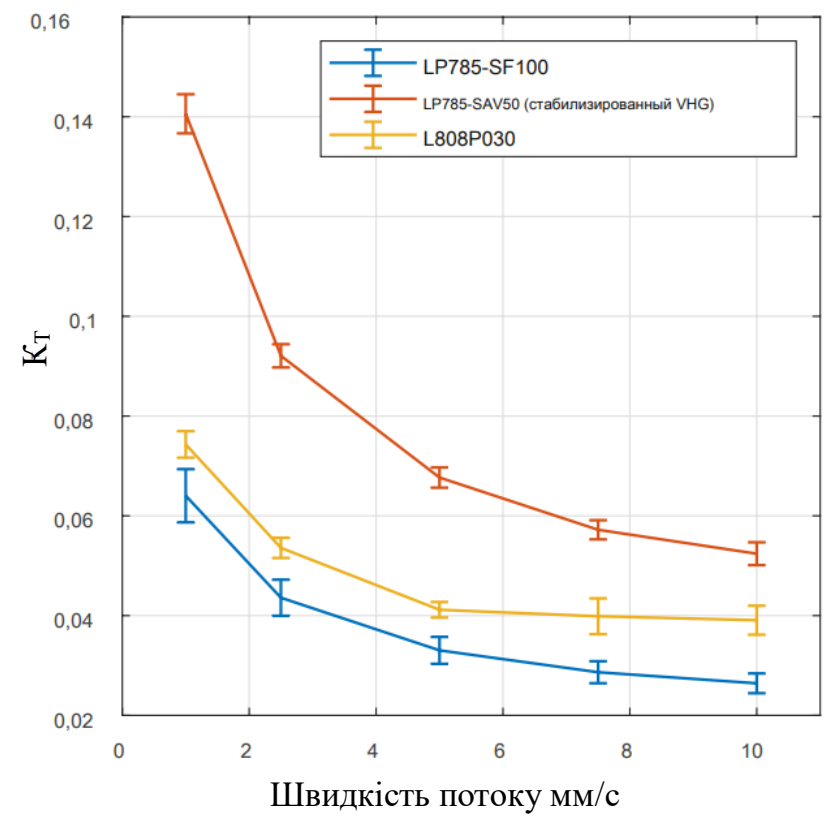

Рисунок 3 - Часовий контраст розрахований для різних швидкостей потоку

Утворений лазерний промінь промінь падає на матове скло 3 (Edmund Optics), яке повільно обертається двигуном 4 (швидкість обертання 1 об./год.). Світло, що проходить через матове скло, розсіюється і проходить на поляризатор 5 у вигляді розширеної світлової плями. Ефективність такого доповнення описана в роботі [8]. Для вивчення динамічного розширення спекл-зображення автори спочатку застосовують традиційну схему лазерного спекл-контрастного аналізатора. Як видно на рис. 4 (a), контраст значно менший i сигнал залишається дуже зашумленими. Як показано на рис. 4 (b), помітно поліпшена картина з'являється при повільному обертанні матового скла приблизно з одним обертом в годину i побудові графіку з серії зображень.

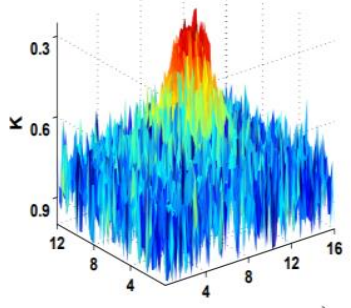

a)

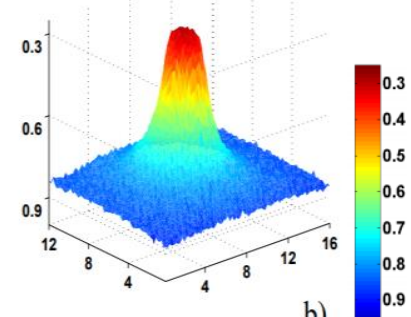

b)
Рисунок 4 - Тривимірний графік лазерного спекл-контрастного зображення рідкого включення в твердому блоці тефлону. а) Зображення 3 розширенням $80 \times 60$ пікселів, усереднене по 500 окремим вимірам. б) Модель побудована 3 використанням активного шумозаглушення. 
Поляризатор 5 прибирає зайві коливання i далі промінь потрапляє на фокусуючий об'єктив 6. Для даного пристрою об'єктиви 6 та 10 були обрані 3 фокусуванням 10x для чіткого збільшеного зображення на екрані. Після виходу 3 об'єктиву промінь подається в гнучке оптоволокно 7 для більш зручного позиціонування променя на біологічний об'єкт 8. Відбиту спекл картину фіксує КМОП камера 9 через об'єктив 10. Для дослідження спекл-контрасту була обрана Basler acA2040-180km. Компанія Basler спеціалізується на виробництві камер для технічних потреб, в тому числі для мікроскопії в медицині та біології. Конкретно ця модель була обрана через розширення 2048×2048 пікселів, та розмір пікселя 5,5 мкм для якісного відображення картини. Камера підключена до ПК 11 для обробки та подальшого аналізу даних спекл-контрастного аналізу.

\section{V. ВИСНОВКИ}

Не зважаючи на те, що метод лазерної спекл-контрастної візуалізації знаходяться на етапі розвитку, він вже знаходять широке застосування в наукових дослідженнях в області фізіології i патофізіології кровообігу. Методика є дуже перспективною для досягнення високої роздільної здатності in vivo (на рівні десятків мікрометрів та мілісекунд) візуалізації змін кровотоку як для дослідницьких цілей, так і для клінічної діагностики найближчим часом. Це дозволяє вже сьогодні ставити і вирішувати певні прикладні медичні та медикотехнічні завдання. Використання інших методів для дослідження судин хоча і дає змогу лікарям отримувати інформацію про кровоносні структури, має ряд недоліків, які може компенсувати спекл-контрастна методика. Саме тому потрібно активно впроваджувати оптичні методи дослідження процесів мікрогемодинаміки та судин.

Проаналізувавши основні особливості методики лазерного спеклконтрастного аналізу, та інші наукові роботи на цю тему, була створена схема отичного діагностичного пристрою. Був описаний принцип дії та вибір конкретних складових для реалізації прибору.

$$
\text { Пристрій передбачається }
$$

використовувати для аналізу динаміки кровотоку in vivo при вирішенні низки практичних завдань в медицині. Це може бути діагностика гострого панкреатиту та панкреонекрозу, бо які б не були причини виникнення цього захворювання, основна роль його прогресування, 3 наслідками у вигляді тканинної гіпоксії і (або) аноксії, належить до мікроциркуляторних порушень. Оцінка перфузії тканин в режимі реального часу дозволить розширити можливості малоінвазивних технологій, в оцінці стану тканини підшлункової залози, ранній діагностиці та лікуванні різних ускладнень гострого панкреатиту. Цукровий діабет також викликає функціональні та морфологічні зміни в кровоносних судинах. Пристрій може детектувати зміни мікроциркуляції крові в підшлунковій залозі в умовах розвитку діабету. Експерименти по застосуванні лазерного спекл-контрастного аналізу для діагностування цих хвороб на лабораторних тваринах були представлені в роботах[6,9]. В роботі [10] подібний пристрій використовували в in vivo діагностиці для візуалізації кровотоку сітківки. Оскільки мікроциркуляція $є$ критичним фізіологічним параметром, i його порушення пов'язане 3 ранніми стадіями багатьох захворювань сітківки, лазерний спекл-контрастний аналіз може надати цінну фізіологічну інформацію i служити раннім сурогатним маркером для низки офтальмологічних порушень.

\section{ПЕРЕЛІК ПОСИЛАНЬ}

[1] Бойко В. В., Павлов А. А., Жаров А. В., Методы исследования нарушений микроциркуляторного звена системного кровообращения. Питання анестезіології i реаніматології. Харківська хірургічна школа. №4(42). 2010p.

[2] Рогаткин Д.А., Физические основы современных оптических методов исследования микрогемодинамики in vivo. Медицинская физика. 2017p., № 4

[3] Бархатов И. В., Применение лазерной допплеровской флоуметрии для оценки нарушений системы микроциркуляции крови человека. Казанский медицинский журнал, 2014p., том 95, №1

[4] Сдобнов А.Ю., Кальченко В.В., Быков А.В., Попов А.П., Молодый Г., Меглинский И.В., Визуализация кровотока методом лазерных спекл-контрастных 
измерений в условиях неэргодичности. Оптика и спектроскопия, 2020p, том 128, вып. 6. С. 773-780.

[5] Fercher A., Briers J. Flow visualization by means of singleexposure speckle photography. 1981p.

[6] Тимошина П. А., Мониторинг микроциркуляции крови методом спеклконтрастной визуализации в исследованиях модельных патологий на животных, 2016р.

[7] Postnov D. D., Xiaojun C, Sefk Evren Erdener, Boas D. A., Choosing a laser for laser speckle contrast imaging, 2019p.

[8] Völker A.C., Zakharov P., Weber B., Buck F., Scheffold $\mathrm{F}$., Laser speckle imaging with an active noise reduction scheme, 2005p.

[9] Потапова Е.В., Серёгина Е.С., Дрёмин В.В., Ставцев Д.Д., Козлов И.О., Жеребцов Е.А., Мамошин А.В., Иванов Ю.В., Дунаев А.В., Лазерная спекл-контрастная визуализация микроциркуляции крови в тканях поджелудочной железы при лапароскопических вмешательствах, «Квантовая электроника», 50, № 12020 p.

[10] Haiying Cheng, Duong T.Q., Simplified laser-speckleimaging analysis method and its application to retinal blood flow imaging. 2007p. 


\title{
ЛАЗЕРНЫЙ СПЕКЛ-КОНТРАСТНЫЙ АНАЛИЗ ДЛЯ ИССЛЕДОВАНИЯ МИКРОЦИРКУЛЯЦИИ В СОСУДАХ
}

\author{
Богомолов Н.Ф., \\ к.т.н.., дочент \\ nbogom@yahoo.com \\ Пузик М.Ю., бакалавр \\ Max.Puzyk@gmail.com \\ Кафедра биомедицинской инженерии \\ Национального технического университета Украины \\ «Киевский политехнический институт имени Игоря Сикорского», \\ г. Киев, Украина
}

Реферат - Предложенная разработка диагностического лазерного устройства, использующего методику спеклконтрастного анализа іn vivo для исследования микрочиркулячии в сосудах. Проведён краткий обзор существующих методов исследования микроциркуляции. Рассмотрены основные особенности методики измерения лазерного спекл-контрастного анализа Предложена общая структурная схема диагностического устройства с указанныли моделями компонентов.

Ключевые слова - Микрочиркуляция, спекл, спекл-контрастный анализ.

UDC 616-002, 621.382.2

\section{LASER SPECKL-CONTRAST ANALYSIS FOR STUDYING MICROCIRCULATION IN VESSELS}

Bogomolov M.F., Ph.D., Associate Professor nbogom@yahoo.com Puzyk M.Yu., student Max.Puzyk@gmail.com

Department of Biomedical Engineering National Technical University of Ukraine "Igor Sikorsky Kyiv Polytechnic Institute",

Kiev, Ukraine

\begin{abstract}
Proposed development of a diagnostic laser device using the in vivo speckle contrast analysis technique to study microcirculation in blood vessels. A brief review of the existing methods of microcirculation research is carried out. The main features of the measurement technique for laser speckle contrast analysis are considered. A general block diagram of a diagnostic device with the indicated component models is proposed.
\end{abstract}

Key words - Microcirculation, speckle, speckle contrast analysis. 